\title{
Gender Inequality in the Usage of ICT Facilities in Academic Libraries: A Case Study of Presbyterian University College Library (PUCL), Ghana
}

\author{
Frank Afoakwa Boateng $^{1} \quad$ Samuel Ameyaw $^{2}$ \\ 1.Presbyterian University College, Ghana (PUCG), Asante Akyem Campus \\ 2.Valley View University (VVU), Oyibi - Accra, Ghana
}

\begin{abstract}
The purpose of the study was to find out gender inequality in the use of ICT facilities in the library among male and female students in the Presbyterian University College of Ghana-Asante Akyem Campus-Ghana. It was a case study which adopted the survey approach with questionnaires as the data collection instrument to solicit the opinions of both genders. The findings disclosed that ICT facilities are available in the library and a significant number of both genders have access to the facilities. However, there were slight variations in the use of the facilities in some domain.Poor internet services, as well as inadequate power supply, were identified as significant challenges that impeded the use of ICT facilities in the library; therefore, it is recommended that measures should be put in place to avoid persistent power failure in the library. Lastly, management of the university should acquire bigger broadband to improve the internet service in the library.
\end{abstract}

Keywords: Asante Akyem, Gender, Ghana, ICT facilities, Inequality, Presbyterian, Students, University College.

DOI: $10.7176 / \mathrm{JEP} / 10-2-05$

\section{Introduction}

Education has always been trumpeted as an instrument that prepares both male and female students to face the challenges ahead of them in all spheres of life including their environment. The issue of gender inequality is not limited to labour market discrimination when male and female with the same qualification, experience, and training apply for a position, but as a result of gender discrimination, the male is selected during recruitment.

Similarly, the story is not restricted to only labour market but has spread throughout all the educational institutions where male and female students consider themselves that some programmes are meant for only males and these courses are the no-go area for female students.

The emergence and introduction of the use of ICT facilities in educational institutions globally did not escape from this perception in various academic institutions which Presbyterian University College; Ghana (PUCG) is no exception. The academic institutions have consistently been dedicated to making teaching, learning, and research easier for lecturers and students through the use of ICT facilities. Currently, no academic institution can survive without the application of ICT facilities in their learning and teaching activities. The adoption of ICT facilities in educational institutions has brought dynamic changes in all sectors of education since ICT has become a potential tool for teaching and learning. Ono and Zavodny (2007) defined information and communication technologies (ICTs) as a digital technology used for communication or information gathering, for instance, mobile phones and computers. Wilson, Ayebi-Arthur, and Tenkorang (2011) were of the view that information and communication technology (ICT) comprises computer hardware and digital/analogue devices and software applications.

Edumadze and Owusu (2013) added that the adoption of Information and Communication Technology (ICT) into the institution of higher learning had enhanced teaching and learning processes as well as students' performance.

Dukić, Dukić, and Kozina (2012) hinted that the constant application of ICT in universities had transformed all academic activities as well as a society into a knowledge economy.

Sosin, Blecha, Agawal, Bartlett and Daniel (2004)“observed that there has been a large-scale development, and use of technology in every area of human activities, including the educational field and this has led to a dramatic change in the methods of instruction for education at all levels, especially the higher education level".

\subsection{Statement of the problem}

The fight for gender equality has gained prominent attention for the past two decades be it social, political, cultural and educational sector. The role and benefits of ICT adoption in academic institutions cannot be overemphasized. Regrettably, management of Presbyterian University College, Ghana (PUCG) has invested heavily in the purchase of ICT facilities to enhance learning and research in the library, from the preliminary observation by the researchers, it appears that there is disparity between male and female students' concerning the use of these facilities in the library; others also expressed their dissatisfaction about the facilities. This observation 
confirmed the studies of Adetimirin (2012; Reffell \& Whitworth, 2002) which reported that the use of ICT facilities in most of the university library in developing nations is far below expectation. Again, there has not been any similar study on gender inequality concerning the use of ICT facilities by students, particularly at the Presbyterian University College, Ghana. However, few studies were carried out elsewhere by Goswami and Dutta (2016; Efuwape \& Aremu, 2013; Kay, 2006; Mahmood, 2009), and in Ghana by Owusu-Ansah, 2013; Amenyedzi, Lartey, and Dzomeku, 2011). It is against this background that the current study was carried to investigate gender inequality in the use of ICT facilities in the library and fill in the gap created.

\subsection{Objectives of the Study}

The research seeks to:

i. Determine the type of ICT facilities available in the library

ii. Find out which gender access ICT facilities in the library

iii. Ascertain gender levels of skills in the use of ICT facilities in the library

iv. Determine which gender uses ICT facilities frequently in the library

v. Find out the challenges associated with the use of ICT facilities in the library

\subsection{Literature Review}

\subsection{Type of ICT Facilities Available in the Library}

The availability of ICT facilities in the academic environment is one of the motivational forces that attract students to use the facilities for learning and research purposes; it also goes a long way to enhance students' performance. In view of this, it is therefore imperative for every academic institution to provide and make ICT facilities available to all students without discrimination.

In support of making ICT facilities available in academic institutions, the study of Kinengyere (2006) reported that the "available resources were not utilized by both male and female users of the library because they were not aware of the resources." Aryatuha (2007) pointed out that the availability of computer hardware and software should go together with the training facilities of the learners as well as continuous technical support. A similar study by Ojeniyi and Adetimirin (2013) on gender influence in ICT use by undergraduates in two University Libraries in Nigeria, enumerated ICT facilities that were available for students as computers system, printers, and photocopiers. The rest are scanners, CD-ROM, internet facilities and online resources. In some cases, the readiness to use the facilities is there, but the difficulty in getting access hinders usage; therefore, it is crucial for managers and university authority to consider accessibility rather than availability. The findings of Khan, Bhatti, and Khan (2011) on ICT use by students of faculty of education at IUB asserted that ICT facilities were available to students in the main library and departmental computer laboratory as well as the university hostel(s).

In a similar study conducted by Adeniji, Adeniji and Ogunniyi, 2011; Etebu, 2010; Abubakar, 2010) disclosed that computers, CD-ROMS, internet, printers were available in the university libraries for use.

A study on internet availability to postgraduate students at the University of Nigeria, Nsuka concluded that $100 \%$ of the students use the internet for their studies (Audu, 2006). Emojorho and Nwalo, (2009) confirmed in their studies that ICT facilities are available in the Nigerian universities' libraries and indicated that the facilities are utilized properly for the intended purpose. The study of Ikolo and Okiy (2012) established that "females use the internet more than males in their study on gender differences in computer literacy among medical students in selected southern Nigerian Universities."

\subsection{Students Access to ICT Facilities}

Students' access to ICT facilities plays a central role in their learning since the necessary resources may be available alright; getting access to such essential facilities to support academic activities sometimes take a different direction which does not support access. Easy access to ICT facilities in the academic library influence both genders to become knowledgeable in searching for relevant information.

It is, therefore, crucial for academic institutions to make sure that their ICT facilities are available and accessible to their users without any restrictions or frustrations to their usage.

Mattheos, Schittek and Attström.(2002) findings reported that out of 590 students of 16 European dental schools from 9 countries revealed that $60 \%$ of students use computers for their education, while $72 \%$ have access to the internet. Uribe and Marino (2006) conducted a similar study with162 student at the School of Dentistry, University of Valparaiso, Chile on the use of ICT. Their results highlighted that all the respondents had access to a computer, while $96.4 \%$ used the internet. According to the study, the majority of the students' access the internet from home while $73.4 \%$ used internet weekly, $92.2 \%$ used it for email, followed by $88.3 \%$ who used it for search engines. It was reported from the study that $21.1 \%$ used the internet to search for dental information for their studies. The findings of Khan, Bhatti, and Khan (2011) on the use of ICT by students hinted that out of 164 respondents, $80(48.8 \%)$ indicated that, they access ICT at their departmental computer laboratory while 52 
$(31.7 \%)$ respondents said they access the internet at their classroom, 15(9.1\%) respondents access it from the library, 5 respondents $(3.0 \%)$ said they access it at their university hostel, $6(3.7 \%)$ respondents also indicated that they access it from the café while $4(2.4 \%)$ of the respondents access it at their friends' homes.

In a similar study by Anunobi (2006) on internet use at the Federal University of Technology, Owerri reported that $87.41 \%$ of the students use the internet while $4.67 \%$ expressed that, they do not use the internet. According to Fatoki (2004) study on the impact of library resources and the internet among undergraduate students in Ibadan reported that $72 \%$ of the students access the internet from the university library's internet services, followed by $35 \%$ who access it from the cybercafé, and $5 \%$ stated neither. The study of Egbo, Okoyeuzu, Ifeanacho, and Onwumere (2011) revealed that "female students tended to accept the use of ICT more than their male counterparts." In a related study by Tella and Mutula (2008), on gender difference in computer literacy disclosed that "students with higher computer background were mostly males and were more inclined to access and make good use of library resources than their female counterpart."

\subsection{Gender Levels of Skills in the use of ICT Facilities}

The acquisition of basic computer skills is significant in this era of the technological age where the flow of information is uncontrollable due to the advancement of technology.

The level of ICT skills is no more optional rather, compulsory for every student to be able to apply these skills in their search for relevant information that would enhance their performance. Otokunefor (2005) "explained computer literacy as the level of computer knowledge of an individual and the degree to which such knowledge can be used in problem-solving." The majority of researchers reported that, males owned, use computers and the internet more than females, they also spend a lot of time online, do more technology courses, and exhibit more motivation to study digital skill than the females (Cooper, 2006; Correa, 2010; Fallows, 2005; Livingstone \& Helsper, 2007; Losh, 2004; Pinkard, 2005; Wilson, Wallin, \& Reiser, 2003). According to the study of Van Deursen and Van Dijk (2015) indicated that men recorded higher than women in all the skill domains such as saving files, downloading programs and searching for information. Interestingly, Ritzhaupt, Dawson, and Barron (2013) reported that female students perform better than their male counterparts in all technology literacy domains such as creating new files, locating and opening files, selecting the best device to complete a given assignment.

The rest are selecting the correct printer, setting page margins within a word processing document, editing images, communication and collaboration as well as practical keyboard skills, using e-mail, creating new slides within presentation software, using print preview, deleting data in a spreadsheet, creating concept maps, maintaining password security and identifying security risks. On the contrary, the study of Blankson (2015) reported that "there was no significant difference between male and female students competence in ICT usage, male students demonstrated more competence in the use of ICT than their female counterparts." In a related study by Lau and Yuen (2014) established that female student's perceived internet literacy such as; searching information, using instant messaging, downloading files as well as setting headers in word processing software, plotting a graph with a spreadsheet, editing a photo with image processing software than their male counterparts.

The study of Hew and Leong (2011) on gender difference among pre-university students in Malaysia reported that, there were no significant gender disparities in eight out of nine ICT competencies; however, the male students were slightly ahead in mean score in all the ICT competencies except for word processing competency where female students had a higher mean score. The study stressed further that, females were perceived as better typists and tended to use more word processing applications than their male counterparts. In a related study by Hakkarainen et al., (2000) reported that the ICT skills of male students were found to be higher than their female counterparts. Jorge et al., (2003) also revealed that there was "no significant differences between male and female students' in the use of technologies such as mobile telephones or computers usage." The study of Zin et al. (2000) at Kebangsaan University, Malaysia disclosed that there was a significant disparity in computer literacy level between male and female students. It was revealed that male students had greater computer experience and used the computer more frequently than female students. According to Sajjad and Sumayyah (2009) study in Kuwait, indicated that 11th-grade female governorate high students lacked the skills to formulate search strategies and therefore; do not make good use of the school library. Bassi and Camble (2011) reported that male university students in Adamawa State in Nigeria acquired search skills through library instruction and orientation.

\subsection{Frequency of ICT Facilities use by Gender}

The adage "practice makes a man perfect" implies to every human activity under the sun, to become perfect in any new system, there should be a constant practice for new ideas. The habit of constant practice would not only advance one's ideas but would rather improve one's skills towards the use of the new system and also expose the early challenges of the system.

Fallows (2005; Hargittai \& Walejko,2008) reported in their study that male students use the internet 
frequently than their females counterparts for various purposes such as searching for a job, electronic-posting, and uploading of material. Moe (2004) added that male students use library computers more frequently than female students. According to the findings of the study, 54\% of males use computers more than once a week as against $43 \%$ of female students. Steinerova and Susol (2007) expressed that female's use the internet slightly less than their male counterparts; they also exhibit a greater proportion of rare use and non-use of electronic resources and a lower proportion of frequent use. Interestingly, a study by (Ofcom, 2008) revealed that females use technology more often than males for social networking and creative purposes such as setting up their website or creating an online photo album.

Amkpa (2007) echoed that male and female student vary significantly in their attitudes towards computer applications which eventually have a negative effect on their job opportunities after completion of school.

Looker and Thiessen (2003) asserted that male students use computers more frequently than their female counterparts. According to the study male students were also more knowledgeable in using various computer applications than their female counterparts. Valentine et al. (2005) disclosed that male students have greater access to hardware and spend more time using computers outside the school for leisure purposes, while females are significantly more likely to use computers for academic activities than their male counterparts. Jones et al. (2009) reiterated in their studies that males spent more time online searching for information and were more likely to go online overnight than females. Nwezeh (2010) and Rodríguez (2006) on undergraduates' frequency of ICT use indicated that students use computers daily. In a similar study by Fabunmi (2012) on undergraduates' perception of the effectiveness of ICT use in Ekiti State University, Nigeria confirmed that $70(35 \%)$ of the respondents used the computer once a week, 140(70\%) used CD-ROM occasionally. Sahin, Balta, and Ercan (2010) conducted a study on the use of internet resources by university students. According to the study, university students use email and forum chat-line frequently in their daily activities. Surprisingly, the study revealed that students do not use internet resources for their studies. Akande and Bamise (2017) added that male students use the internet frequently than their female counterparts. Similarly, Ellore, Niranjan and Brown (2014) confirmed in their study that male students spend adequate time on the internet as compared to their female colleagues. Ibegwam (2004) took a study on the use of the internet by students of the College of Medicine, University of Lagos, Nigeria. The findings revealed that all the 200 respondents who took part in the study, used the internet facilities, according to the study, most of the students used the internet to look for academic information and also visit other university websites.

\subsection{Challenges Associated with the use of ICT Facilities}

There is no complete set of a system without challenges surrounding its usage. The only antidote to such difficulties is one's readiness/preparedness, attitude and perception towards the system.

In an attempt to use a new system, people should be ready to accept challenges that will confront them in their course of using or learning how to use the ICT facilities in their studies.

Enochsson (2005) hinted that the socio-cultural background plays a key role leading to computer anxiety and feelings of low esteem among females in the use of technology. In a related study by Martey (2004) highlighted that the acceptance of ICT by libraries from 1996-2004, witnessed the slow application of ICT.

The findings of the study accredited to a slow pace in the acceptance of ICT to the high cost of ICT infrastructure as well as lack of technical know-how. Tella and Mutulu (2008) added that one of the causes of low use of technology by females is lack of relevant competencies which affects them more than males.

Ford et al., (2001) reiterated that females find it tough to use technology when it comes to searching for information online than males. Salako and Tiamiyu (2007; Corbett \& Williams, 2002) did a study on undergraduates students in developing and developed countries and enumerated some factors that hinder ICT usage as; gender, age, accessibility, academic discipline and lack of ICT skills. Luambano and Nawe (2004) also carried out a similar study on internet use by students of the University of Dar es Salaam. According to the survey, the majority of the students did not use the internet because of insufficient computers, lack of skills in internet use and slow speed of computers. In a related study by Amenyedzi, Lartey, and Dzomeku (2011) on the use of computers and internet as a supplementary source of educational material in three Senior High Schools in Ghana also enumerated similar challenges as; insufficient computers in the computer laboratories as well as poor internet services. The study of Hennessy and Harrison et al., (2010) also revealed that the majority of the students in the developing nations lack sufficient searching skills when using ICT facilities for their learning purpose. Nwokedi (2007) supports the views of other authors that lack of adequate skills in searching for information is still hindering the use of ICT / internet facilities in some academic institutions. Salaam and Adegbore (2010) affirmed that one of the key problems facing the use of internet facilities is the unstable power supply in the university environment in some African countries.

Okiki and Asiru (2011) expressed that "slow internet connectivity and incessant power outage are some of the challenges that affect the use of electronic resources." In a related study by Ojokoh and Asaolu (2005) also hinted that poor internet services, as well as an inconsistent power supply in Nigeria, are the major challenges 
confronting the use of electronic resources.

\subsection{Methodology}

The study adopted the survey design approach with the use of the questionnaire as the instrument to gather data from the respondents. The population for the study comprised of all male and female students in the University. The total population of the students at the time of conducting this study was one thousand four hundred and thirty-eight $(1,438)$. The simple random sampling technique was used to sample two hundred and eighty-eight (288) from the population. Nwana(1981) recommended that "if the population is a few hundred, a $40 \%$ or more sample will suffice, if many hundreds, a $20 \%$ sample will do, if a few thousands, a $10 \%$ sample will do; and if several thousand, a $5 \%$ or less sample will be representative of the population". Based on the Nwana's recommendations, $20 \%$ of the population was considered an appropriate sample size, thus, (288) was selected. Two hundred and eighty-eight (288) questionnaires were administered to the participants and out of this number; two hundred and sixty-seven (267) were filled correctly, hence, representing $92.71 \%$ response rates. The statistical package for social sciences (SPSS 17.0) was employed to analyze the data.

\subsection{Analysis of Data and Discussions}

According to Thanuskodi (2012), the analysis of data is the final point in the research process, and it is the link between raw data and significant results leading to conclusions. Data was collected through the use of a structured questionnaire. The Statistical Package for Social Sciences (SPSS, 17.0) was used to analyse the quantitative data.

\section{Figure 1: Gender Distribution.}

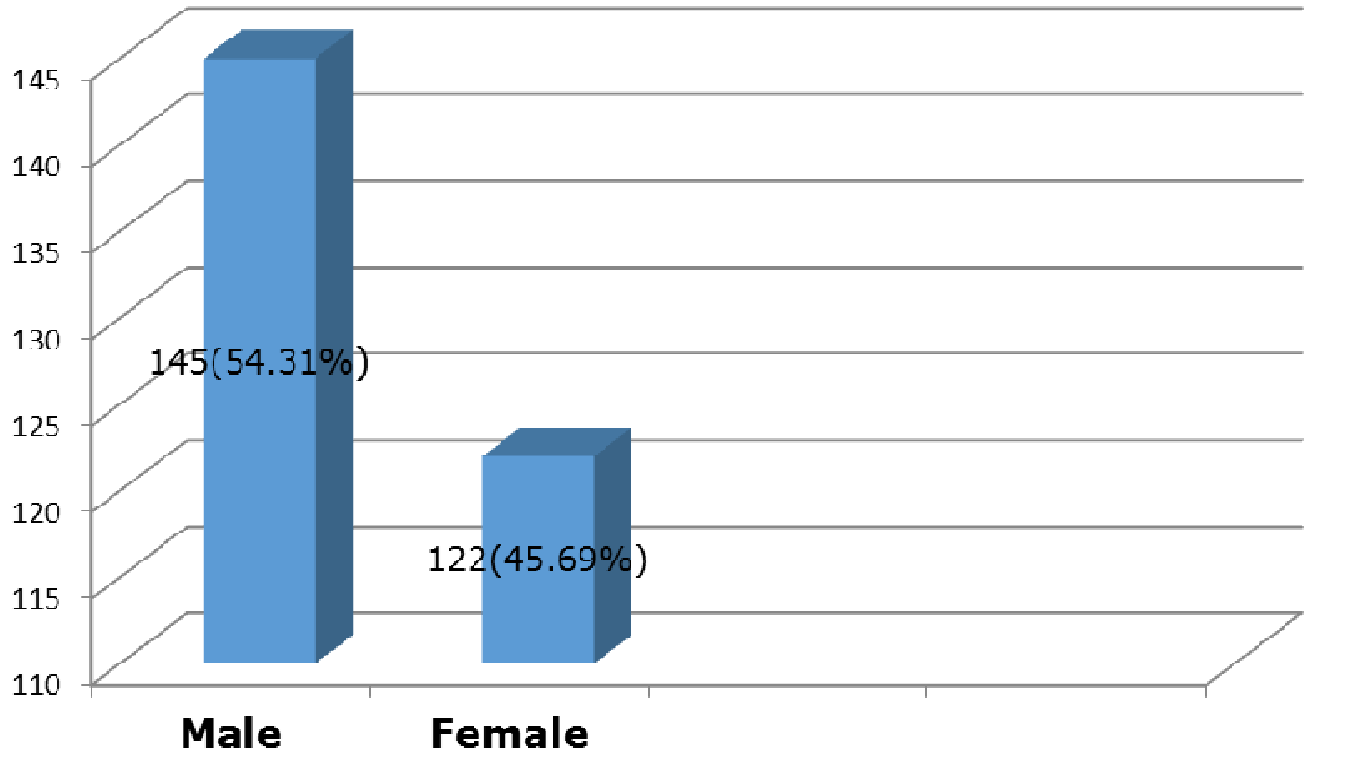

\section{Sources: Field Data, 2018.}

From figure1, it was reported that out of 267 respondents who participated in the study $122(45.69 \%)$ were female whereas $145(54.31 \%)$ were male.

\subsection{ICT Facilities Available in the Library}

The availability of ICT facilities in the academic libraries promotes constant usage by both genders irrespective of their educational levels and skills. The researchers sought to find out the availability and use of ICT facilities by both genders; the responses are displayed in Table 4.1 below. 
Table 4. 1: ICT Facilities Available in the Library

ICT facilities Available in the University

\begin{tabular}{|l|l|l|l|l|l|c|l|}
\hline \multicolumn{2}{|l|}{ Option } & $\begin{array}{l}\text { Available } \\
\text { Frequency }\end{array}$ & $\mathbf{( \% )}$ & $\begin{array}{c}\text { Unavailable } \\
\text { Frequency }\end{array}$ & $\mathbf{( \% )}$ & $\begin{array}{c}\text { Undecided } \\
\text { Frequency }\end{array}$ & $(\%)$ \\
\hline \multirow{2}{*}{ Computers } & Male & 128 & $(88.27 \%)$ & 6 & $(4.14 \%)$ & 11 & $(7.59 \%)$ \\
\cline { 2 - 9 } & Female & 98 & $(80.3 \%)$ & 16 & $(13.1 \%)$ & 8 & $(6.6 \%)$ \\
\hline \multirow{2}{*}{ Snternet } & Male & 129 & $(89 \%)$ & 7 & $(4.8 \%)$ & 9 & $(6.2 \%)$ \\
\cline { 2 - 9 } & Female & 109 & $(89.3 \%)$ & 9 & $(7.4 \%)$ & 4 & $(3.3 \%)$ \\
\cline { 2 - 9 } & Male & 39 & $(26.9 \%)$ & 80 & $(55.2 \%)$ & 26 & $(17.9 \%)$ \\
\cline { 2 - 8 } & Female & 31 & $(25.4 \%)$ & 72 & $(59 \%)$ & 19 & $(15.6 \%)$ \\
\hline \multirow{2}{*}{ Printers } & Male & 120 & $(82.76 \%)$ & 11 & $(7.59 \%)$ & 14 & $(9.65 \%)$ \\
\cline { 2 - 8 } & Female & 99 & $(81.15 \%)$ & 13 & $(10.66 \%)$ & 10 & $(8.19 \%)$ \\
\cline { 2 - 8 } & Male & 110 & $(75.9 \%)$ & 24 & $(16.5 \%)$ & 11 & $(7.6 \%)$ \\
\cline { 2 - 8 } & Female & 91 & $(74.6 \%)$ & 12 & $(9.8 \%)$ & 19 & $(15.6 \%)$ \\
\hline
\end{tabular}

\section{Source: Field Data, 2018}

The results from Table1 reported that out of 145 male respondents, $128(88.27 \%)$ indicated that there are computers available for use, while $6(4.14 \%)$ of the respondents indicated unavailable to the statement and $11(7.5 \%)$ remain undecided. Similarly, on the part of the female respondents, $98(80.3 \%)$ of the respondents hinted that there are computers available to the statement, followed by $6(13.1 \%)$ who said unavailable to the assertion and $11(6.6 \%)$ remain undecided. Again, to ascertain whether internet facilities are available in the library, $129(89 \%)$ of the male respondents said internet facilities are available in the library, while 7 (4.8\%) indicated unavailable. In the same way, female respondents $109(89.3 \%)$ said internet facilities are available in the library, followed by $9(7.4 \%)$ who indicated unavailable to the statement. The findings of internet availability and use gave an interesting revelation that female respondents were slightly ahead of their male counterparts. To find out whether photocopiers are available for students, $120(82.76 \%)$ of the male respondents said photocopiers are available for use, only $11(7.59 \%)$ said unavailable. Equally, $99(81.15 \%)$ of the female respondents also indicated that photocopiers are available for use, on the contrary, $13(10.66 \%)$ reported on unavailable to the question. It is seen from the findings that regarding photocopiers availability, male respondents were ahead of their female counterparts.

\subsection{Gender Access to ICT Facilities}

The provision of access to ICT facilities in the library is very paramount since availability does not mean accessibility. The learning facilities may be available for students, but then, getting access to these facilities takes too much time, and in some cases, students abandoned its patronage due to difficulties and frustrations. The below table sought the views of the respondents whether they have access to the ICT facilities in the university.

Table 4. 2: Gender Access to ICT Facilities

\begin{tabular}{|lllll|} 
Responses & Male & Fercentage $(\%)$ & Frequency & Percentage $(\%)$ \\
\hline Yes & Frequency & Per) & 112 & $(91.80 \%)$ \\
\hline No & 131 & $(90.34 \%)$ & 10 & $(8.19 \%)$ \\
\hline Total & 14 & $(9.66 \%)$ & $\mathbf{1 2 2}$ & $\mathbf{1 0 0}$ \\
\hline
\end{tabular}

Source: Field Data, 2018.

The findings from Table 2 indicated that out of 145, 131 (90.34\%) of the male respondents reported that they have access to ICT facilities in the library, while $14(9.66 \%)$ indicated "No" to the statement. On the part of the female, out of 122 respondents, $112(91.80 \%)$ said that ICT facilities are accessible. It can be concluded from the findings that the majority of the female students were slightly ahead of their male counterparts concerning the accessibility of ICT facilities.

This can be ascribed to their positive attitude and perception towards ICT facilities in the library.

\section{3: Gender Levels of Skills in the Use of ICT Facilities}

ICT skills include the competence to use the facilities and control all the devices to obtain the desired results. Otokunefor (2005) "explained computer literacy as the level of computer knowledge of an individual and the degree to which such knowledge can be used in problem-solving." 
Table 3: Gender Levels of Skills in the Use of ICT Facilities

\begin{tabular}{lllll} 
Skills in the Use of ICT & $\begin{array}{l}\text { Male } \\
\text { Frequency }\end{array}$ & Percentage (\%) & $\begin{array}{l}\text { Female } \\
\text { Frequency }\end{array}$ & $\begin{array}{l}\text { Percentage } \\
(\mathbf{\% )})\end{array}$ \\
Using Computer to type & 21 & $(14.48 \%)$ & 27 & $(22.13 \%)$ \\
\hline Scanning of documents & 11 & $(7.59 \%)$ & 10 & $(8.20 \%)$ \\
\hline Uploading /Downloading of files & 103 & $(71.03 \%)$ & 77 & $(63.11 \%)$ \\
\hline Navigating on the internet & 10 & $(6.90 \%)$ & 8 & $(6.56 \%)$ \\
\hline Total & $\mathbf{1 4 5}$ & $\mathbf{1 0 0}$ & $\mathbf{1 2 2}$ & $\mathbf{1 0 0}$ \\
\hline
\end{tabular}

Source: Field Data, 2018

Table 3 sought to find out gender levels of skills in the use of ICT facilities. It was revealed that out of 145 males, $101(69.66 \%)$ of the respondents used ICT facilities to upload/download files, while $21(14.48 \%)$ used the computers to type their assignments. On the side of the female, out of $122,77(63.11 \%)$ of the female respondents used ICT facilities to upload/download files while $27(22.13 \%)$ used the computers to type their assignments. Strangely, when it comes to uploading/downloading of files, male respondents were ahead of their female counterparts, while the majority of the female students were ahead of their male counterparts when it comes to using computers to type an assignment.

\subsection{Frequency use of ICT Facilities by Gender}

The study examined the frequency of use of ICT facilities by respondents to find out how often they use the facilities. This statement represents one of the main objectives the study sought to find answers to.

Table 4.4: Frequency use of ICT Facilities by Gender

\begin{tabular}{lllll} 
Frequency of Usage & \multicolumn{2}{c}{ Male } & Female & \\
& Frequency & Percentage $(\%)$ & Frequency & Percentage (\%) \\
\hline Daily & 107 & $(73.79 \%)$ & 67 & $(54.92 \%)$ \\
\hline Once a week & 11 & $(7.59 \%)$ & 14 & $(11.48 \%)$ \\
\hline Once a month & 15 & $(10.34 \%)$ & 33 & $(27.04 \%)$ \\
\hline Total & 12 & $(8.28 \%)$ & 8 & $(6.56 \%)$ \\
\hline
\end{tabular}

Source: Field Data, 2018.

From Table 4, the results revealed that the majority of the respondents, that is, $107(73.79 \%)$ and $67(54.92 \%)$ of male and female respondents respectively, indicated that they use ICT facilities daily, while $11(7.59 \%)$ of the male respondents use the facilities once in a week, followed by $14(11.48 \%)$ female respondents who said they use the facilities once in a week. On the other hand, 15(10.34\%) and 33(27.04\%) of male and female reported using ICT for two weeks. The findings stressed further that $12(8.28 \%)$ and $8(6.56 \%)$ of the male and female respondents use them once in a month respectively. From the findings, it implies that male students use the facilities daily than their female counterparts.

\section{5: Challenges Associated with the Use of ICT Facilities by Gender}

The issue of challenges faced by both genders in an institution of higher learning when using ICT facilities is a critical factor that needs to be looked at. The researchers sought to find out the challenges associated with the use of ICT facilities by both genders; the responses are displayed in Table 5 below.

Table4. 5: Challenges Associated with the Use of ICT Facilities by Gender

\begin{tabular}{lllll} 
ICT Challenges & \multicolumn{2}{c}{ Male } & \multicolumn{3}{c}{ Female } & Percentage (\%) \\
Lack of ICT staff & Frequency & Percentage (\%) & Frequency & $(1.64 \%)$ \\
\hline Inadequate computers & 4 & $(2.76 \%)$ & 2 & $(10.66 \%)$ \\
\hline Poor power supply & 11 & $(7.59 \%)$ & 13 & $(39.34 \%)$ \\
\hline Slow internet speed & 49 & $(33.79 \%)$ & 48 & $(48.36 \%)$ \\
\hline Total & 81 & $(55.86 \%)$ & 59 & 100 \\
\hline
\end{tabular}

Source: Field Data, 2018.

The results presented in Table 5 above revealed that $81(55.86 \%)$ and $59(48.36 \%)$ for male and female respondents respectively admitted that slow internet speed was a key challenge.

The next main concern of both genders was the inadequate power supply with male $49(33.79 \%)$ and female $48(39.34 \%)$ respectively. From the results, both male and female respondents admitted that slow internet speed was their biggest challenge. 


\subsection{Discussion, Conclusion, and Recommendations}

The gender difference has become one of the critical subjects of late. Majority of the public and private institutions, as well as individuals, have been advocating for gender equality in educational institutions. This present study examined gender inequality in the use of ICT facilities at the Presbyterian University CollegeAsante Akyem Campus, Ghana.

\subsection{Availability and use of ICT Facilities by Both Genders}

The findings of the study revealed that a significant number of both genders admitted that there are computers, internet, scanners, photocopiers and printers in the university library. This result of the present study is not in contrast with Khan, Bhatti, and Khan (2011) whose study affirmed that ICT facilities were available to students in their main library. The finding is also in line with Adeniji, Adeniji and Ogunniyi(2011; Etebu, 2010; Abubakar, 2010) whose studies established that computers, CD-ROMS, internet, and printers were available in the libraries.

The findings of the availability and use of ICT facilities by both genders revealed that female respondents were a little ahead of their male counterparts regarding internet use. The results of this study confirmed that of Ikolo and Okiy (2012) which reported that "females' students use the internet more than males in their study on gender differences in computer literacy among medical students in selected southern Nigerian Universities."

\subsection{Gender Access to ICT Facilities in the Library}

Accessibility and availability are twins that always join hands together. This implies that when the facilities are available, students can access them for all their academic needs.

The findings revealed that the majority of female respondents have access to ICT facilities which is slightly ahead of their male counterparts. This is also in line with the study of Egbo et al., (2011) that "female students tended to accept the use of ICT facilities more than their male counterparts."

\subsection{Gender Levels of Skills in the Use of ICT Facilities}

Another interesting result from this study is gender levels of skills in the use of ICT facilities in the university. Surprisingly, it was established that when it comes to uploading/downloading of files, male students were ahead of their female counterparts, while the majority of the female students were ahead of their male counterparts, regarding using computers to type assignments. This finding did not affirm the study of Jorge et al., (2003) which reported that there were no significant differences between male and female students' in the use of technologies.

\subsection{Frequency use of ICT Facilities by Gender}

The findings on the frequent use of ICT facilities revealed that male respondents use the ICT facilities daily than their female counterparts. This can be ascribed to their readiness, willingness, and skills to use the ICT facilities. This finding is in line with the study of Looker and Thiessen (2003) on gender differences and computer usage in Canada which reported that male students use computer facilities more frequently than female counterparts.

\subsection{Challenges Associated with the Use of ICT Facilities}

The findings on challenges associated with the use of ICT facilities in the university did not give any divergent view by both genders. Both male and female respondents respectively admitted that slow internet speed was a key challenge. The next main concern of both genders was the poor power supply. This finding supported the study of Okiki and Asiru (2011; Ojokoh \& Asaolu,2005) whose study reported on slow internet connectivity and persistent power outage as some of the challenges confronting students of the Federal University of Technology, Akure, all in Nigeria.

\section{Conclusion}

The findings of the study established that both genders admitted that there are ICT facilities available in the university library, and overwhelming numbers of students have access to the facilities in the library.

The study also found out that male and female respondents have basic skills in computing and this helps them to use the ICT facilities in the library to upload /download files as well as typing. It was also reported that the gap between male and female respondents on ICT facilities use is not significant since both genders perform differently concerning each one of the questions. The findings of the study discovered that the major challenge impeding the use of ICT facilities in the library by both male and female is the slow speed of the internet and inconsistent power supply.

\section{Recommendations}

Based on the findings of the study, the following recommendations were made to the university authority: 
The university authorities should have a compulsory ICT course in their curricula for all students; this will help students to acquire basic and practical skills required of them in this era of information and communication technology. There should be a regular capacity building process such as seminars and workshops for students in the university irrespective of their level and skills in ICT use.

The university authority should purchase new broadband that has a higher capacity to increase the speed of the internet in the university library, thereby saving the time of students who use the ICT facilities.

The use of ICT facilities cannot be accomplished without the appropriate and reliable power supply in the university environment, it is, therefore, recommended that the university authority should improve upon power supply in the university campus to ensure that there is an uninterrupted flow of power in the library. To maximize the use of ICT facilities in the library, library management should provide adequate ICT infrastructure as well as a standby generator for the university library.

Lastly, both genders should be given an equal opportunity to attend ICT workshops, seminars, orientations as well as any other training that would be organized by the university management.

\section{REFERENCES}

Abubakar, B. M. (2010). Availability and Use of Information and Communication Technology (ICT) in Six Nigerian University Library Schools. Library Philosophy and Practice, Available at http://unllib.unl.edu/LPP/bappah-abubakar.pdf.

Adeniji, M.A., Adeniji, .S.E., \& Ogunniyi, S. (2011). Availability and Use of ICT in Olabisi Onabanjo University Library. PNLA Quarterly, 75(3).

Adetimirin, A. E. (2012). ICT Literacy among undergraduates in Nigerian Universities. Education and Information Technologies, 17(4), pp.387-397.

Akande, S. O. \& Bamise, O. F. (2017). The Role of School Library in Academic Motivation of

Secondary School Students in Osun State, Nigeria. International Journal of Library Science. Scientific \& Academic Publishing, 6(1), pp. 18-27.DOI:10.5923/j.library.20170601.03. http://journal.sapub.org/library.

Amenyedzi, F. W. K., Lartey, M. N., \& Dzomeku, B. M. (2011). The use of computers and internet as a supplementary source of educational material: A case study of the Senior High Schools in the Tema Metropolis in Ghana. Contemporary Educational Technology, 2(2), 151-162.

Amkpa, S.A. (2007). Gender and age difference in computer use and attitude among students of the University of Maiduguri. Inform. Technol.4 (1) , pp.60-67.

Anunobi, C. V. (2006). Survey on the impediments to students' use of Internet facilities. The Information Technologist, 3(2), pp.40-50.

Aryatuha, H. (2007). The relationship between computerization and organizational effectiveness in the day to day running of business at MOH Headquarters in Kampala. Unpublished Masters Dissertation, Makerere University, Kampala, Uganda.

Audu, C. D. (2006). Internet availability and use by postgraduate students of the University of Nigeria, Nsukka. Global Review of Library and Information Sciences, 2, pp.34-43.

Bassi, M.D. \& Camble, E. (2011). Gender differences in the use of electronic resources in university libraries of Adamawa State, Nigeria. Library Philosophy and Practice. Available at: http://www. digitalcommons.unl.edu/libphilprac/549

Blankson, H. (2015). Establishing the level of Awareness of ICT in Second Cycle Institutions. Journal of Applied Research (AJAR), (1)1, pp.273-285.

Cooper, J. (2006).The digital divide: The special case of gender. Journal of Computer Assisted Learning, 22, $320-334$.

Corbett, B.A. \& Williams,J. D. (2002). Canadian students' access to and Use of Information and Communication Technology. A paper presented at the Pan-Canadian Educational Research Agenda Symposium "Information Technology and Learning", Montreal, Quebec.

Correa, T. (2010).The participation divide among "online experts": Experience, skills, and psychological factors as predictors of college students' web content creation. Journal of Computer-Mediated Communication, 16(1),pp. 71-92.

Dukić, D., Dukić, G.., \& Kozina, G.. (2012). Analysis of students' ICT usage in the function of Croation higher education development management. 19(2), pp. 273-280.

Edumadze, J. K.E., \& Owusu, A.K..(2013).Use of Information and Communication Technology for Teaching and Learning in Ghanaian Universities: Case of University of Cape Coast. International Journal of Computing Academic Research, 2, (6).

Efuwape, B. M., \& Aremu, A. (2013). Gender Differences in Acceptability and Usability of Computer Based Learning Package in Electrical and Electronics Technology in Nigeria. American Journal of Educational Research, 1 (10), pp.419-424. Available at: http://www.pu bs.sciepub.com/education.

Egbo, O. P., Okoyeuzu, C. R., Ifeanacho, I. C., \& Onwumere, J. U. (2011). Gender perception and attitude 
towards e-learning: A case of business students, University of Nigeria. International Journal of Computer Application, 1(2), pp.135-148.

Ellore, S. B., Niranjan, S. \& Brown, U. J. (2014). The Influence of Internet Usage on Academic Performance and Face-to-Face Communication. Journal of Psychology and Behavioral Science. 2(2), pp. 163-186.

Emojorho, D., \& Nwalo, K. I. N. (2009). Availability and use of ICTs in collection management in university and special libraries in the Niger-Delta Region, Nigeria. Library Philosophy and Practice. Available at: http://www. webpages.uidaho .edu/ mbolin/ emojorho-nwalo.htm

Enochsson, .A. (2005). A gender perspective on internet use: consequences for information seeking. Inform. Res. $10(4)$, p.237.

Etebu, T. (2010). ICT Availability in Niger Delta University Libraries, Library Philosophy, and Practice. Available at: http://www.unllib.unl.edu/LPP/etebu3.htm.

Fabunmi, F.A.(2012). Undergraduate Student's perception of the effectiveness of ICT use in improving teaching and learning in Ekiti State University, Ado-Ekiti, Nigeria. International Journal of Library and Information Science, 4(7), pp. 121-130,

Fallows, D. (2005). How men and women use the Internet. Pew Internet and American Life Project. Available at: http:/ /www. pewInternet. org/Reports/2005/How-Women-and- Men-Use-the- Internet.aspx

Fatoki, O. C. (2004). Impact of library resources and the Internet on undergraduate students' research, University of Ibadan, Nigeria. Nigeria Libraries, 38(1), pp. 21-33.

Ford, N., Miller, D., \& Moss, N. (2001). The role of individual difference in Internet searching: An empirical study. J. Am. Soc. Inform. Sci.Technol. 52(12).

Goswami, A., \& Dutta, S. (2016). Gender Differences in Technology Usage. Open Journal of Business and Management, 4, pp. 51-59.

Hakkarainen, K., Ilomäki, L., Lipponen, L., Muukkonen, H., Rahikainen, M., Tuominen, T., Lakkala, M., \& Lehtinen, E. (2000). Students skills and practices of using ICT: results of a national assessment in Finland. Computers and Education, 34, pp.103-117.

Hargittai, E., \& Walejko, .G. (2008).The participation divide: Content creation and sharing in the digital age. Information, Communication \& Society, 11(2), pp.239-256.

Hennessy, S., et al. (2010). Teacher factors influencing classroom use of ICT in sub-Saharan Africa. Itupale Online Journal of African Studies 2(1), pp.39-54.

Hew T. S., \& Leong, L. Y. (2011). An Empirical Analysis of Malaysian Pre-university

Students ICT Competency Gender Differences. International Journal of Network and Mobile Technologies 2 (1), pp.15-29.

Ibegwam, A. (2004). Internet access and usage by students of the College of Medicine, University of Lagos. The Information Technologist, 1(1\&2), pp.81-87.

Ikolo, V. E. \& Okiyi, R. B. (2012).Gender differences in computer literacy among clinical medical students in selected southern Nigeria Universities .http://www. Stanford .edu/ group/ siqss/ it and society/vo1io5/vo1io5ao4.pdf.

Jones, S., Johnson-Yale, C., Millermaier, S., \& Pérez, F. S. (2009). U.S. college students' Internet use: Race, gender and digital divides. Journal of Computer-Mediated Communication, 14, pp.244-264.

Jorge, C. M. H., Gutiérrez, E. R., García, E.G., Jorge M. C. A., \& Díaz, M. B. (2003). Use of the ICTs and the perception of e-learning among university students: A differential perspective according to gender and degree year group. Interactive Educational Multimedia, 7, pp.13-28. Available at: http://www http://greav.ub.edu/iem/ index.php?journal=iem\&page=search\&op=results

Kay, R. (2006).Addressing Gender Differences in Computer Ability, Attitudes and Use: the Laptop Effect. Journal of Educational Computing Research, 34(2), pp.187-211.

Khan, S. A., Bhatti, R., \& Khan, A. A. (2011). Use of ICT by Students: A Survey of Faculty of Education at IUB. Library Philosophy and Practice. Available at: http:/ /unllib. unl . edu/LPP /khan Bhatti -khan.pdf.

Kinengyere, A. (2006). The effects of information literacy on the utilization of electronic information resources in selected academic and research institutions in Uganda. Electronic Library, 25(30), pp.328-341.

Lau, W. W. F., \& Yuen, A. H. K.. (2014). Developing and validating of a perceived ICT literacy scale for junior secondary school students: Pedagogical and educational contributions. Computers and Education, 78, pp. 19.

Livingstone, S., \& Helsper, E. (2007). Gradations in digital inclusion: Children, young people, and the digital divide. New Media and Society 9(4), pp.671- 696.

Looker, E. D., \& Thiessen, V. (2003). The digital divide in Canadian schools: Factors affecting students access to and use of Information Technology. Available at: http:// www. cmec .ca /stats/pcera /RSEvents02/EDLooker_OEN.pdf.

Losh, S., Carol. (2004). Gender, educational, and occupational digital gaps. Social Science Computer Review, 22(2), pp.152-166. 
Luambano, I., \& Nawe, J. (2004). Internet use by students of the University of Dare es Salaam. Library Hi Tech News 21(5), pp.13-17.

Mahmood, K. (2009). Gender, subject and degree differences in university students' access, use and attitudes toward information and communication technology (ICT). International Journal of Education and Development using Information and Communication Technology (IJEDICT), 5 (3), pp. 206-216.

Martey, A. (2004). ICT in distance education in Ghana. Library Hi Tech News, 21(5), pp.16-18.

Mattheos, N., Nattestad, A., Schittek, .M, Attström., R. (2002). Computer literacy and attitudes among students in 16 European dental schools: current aspects, regional differences and future trends. European Journal of Dental Education, 6 (1), pp. 30-35.

Moe, T. (2004). Bridging the "digital divide" In Colorado libraries: Survey results from the Colorado public libraries and the "Digital divide" 2002 study. Public Libraries, pp.1-10.

Nwana, O. C. (1981). Introduction to Education Research for Students Teachers. Ibadan: Heinemann Education Books Ltd.

Nwezeh, C. M. (2010). The Use of ICT in Nigerian Universities: A Case Study of Obafemi Awolowo University, Ile-Ife, Library Philosophy and Practice.

Nwokedi, V. C. (2007). Impact of Internet use on teaching and research activities of the academic staff of Faculty of Medical Sciences, University of Jos: A Case study. Gateway Library Journal, 10 (1), pp.13-22.

Ofcom, (2008). Media Literacy Audit: Report on UK children's media literacy. Available at: http:// www. ofcom .org.uk/advice/media_literacy/medlitpub/medlitpubrss /children/]

Ojokoh, B.A., \& Asaolu, M. F. (2005).Studies on internet usage by students of the Federal University of Technology, Akure. African Journal of library Archive and Information Science, 15 (2), p.149-153.

Okiki, O.C., \& Asiru, S.M. (2011). Use of Electronic Information Sources by Postgraduate Students in Nigeria: Influencing Factors, Library Philosophy, and Practice, pp. 4-6. Online Resources- Students Perspective

Ojeniyi, A. \& Adetimirin, A. (2013) .Gender Influence on ICT Use by Undergraduates in Two University Libraries in Nigeria. Computer Communication \& Collaboration.

Ono, H. \& Zavodny, M. (2007). Digital inequality: A Five-Country Comparison Using Microdata. Social Science Research 36, pp. 1135-55.

Otokunefor, H. O. C. (2005). Information literacy rules the networked world: the implication for librarians and information scientists. Niger biblios, 16(1/2), pp.126-132.

Owusu-Ansah, S. (2013).Application of Information and Communication Technology (ICT): A Comparative Analysis of Male and Female Academics in Africa. Library Philosophy and Practice (e-journal). Available at: http:// www. digitalcommons.unl.edu/libphilprac/1087

Pinkard, N. (2005). How the perceived masculinity and/or femininity of software applications influences students' software preferences. Journal of Educational Computing Research, 32, pp.57-78.

Reffell, P., \& Whitworth, A. (2002). Information fluency: Critically examining IT education. New Library World 103(1182/1183), pp.427-435.

Ritzhaupt, A. D., Liu, F., Dawson, K..,\& Barron, A. E. (2013). Differences in student information and communication technology literacy based on socio-economic status, ethnicity, and gender. Journal of Research on Technology in Education, 45 (4), pp. 291-307.

Rodríguez, G. C. (2006), Educative uses of ICT, technological skills and academic performance of the Venezuelan university students (Barineses): A causal perspective International Journal of Education and Development using Information and Communication Technology (IJEDICT), 2 (4), pp. 28-43.

Sahin, Y. G., Balta, S. \& Ercan, T. (2010). The Use of Internet Resources by University Students during Their Course Projects Elicitation: A Case Study. TOJET: The Turkish Online Journal of Educational Technology,9(2), pp.234-244.

Sajjad, R., \& Sumayyah, A. (2009). Information literacy Skills Among Female Students in Kuwaiti High Schools. Library Review, 58 (8), pp. 607 - 616.

Salaam, M.O., \& Adegbore, A.M. (2010). Internet access and use by students of private Universities in Ogun State, Nigeria. Available at: http:// www. webpages .uidaho .edu/ mb olin/ sala amas eg bo re.htm

Salako, O., \& Tiamiyu, M. (2007). Use of search engines for research by postgraduate students of the University of Ibadan, Nigeria. African Journal of Library, Archives and Information Science, 17(2), pp.103 - 115.

Sosin, K., Blecha, B. J., Agawal, R.,Bartlett, R. L.,\& Daniel, J. I. (2004). Integrating ICT into teaching and learning processes. Economic Journal, 17, (442), pp. 27-48.

Steinerova,. J. \& Susol, J. (2007). User's information behaviour - a gender perspective. Infor. Res. 12(13). Available at http://www. information.net/ir/12-13/paper.320.html.

Tella, A.,\& Mutula,. S.M. (2008). Gender Differences in computer literacy among undergraduate students at the University of Botswana: Implications for library use. Malay. J. Lib. Info. Sci.13 (1),pp.59-76.

Thanuski,S.(2012).Use of E-resources by the students and researchers of Faculty of Arts, Annamalai Unversity, International Journal of Library Science, 1(1), 1-7, http: doi.or g/10.59 23/ j. library.201201.01 
Uribe, S., \& Marino, R. J. (2006). Internet and information technology use by dental students in Chile. European Journal of Dental Education, 10 (3), pp.162-168.

Valentine, G.., et al., (2005). Children and Young People's Home Use of ICT for Educational Purposes: The impact on Attainment at Key Stages 1 - 4. Available at: http:// www .dfes.gov.uk/research /data/ uploadfiles/RB672.pdf]

Van Deursen, A. J. A. M.,\& Van Dijk, .A. G. M. (2015). Internet skills levels increase, but gaps widen: a longitudinal cross-sectional analysis (2010-2013) among the Dutch population. Information, Communication and Society, 18(7), pp.782 - 79.

Wilson, K. B., Ayebi-Arthur, K., \& Tenkorang, E. Y. (2011). ICT integration in teacher education - a study of University of Education, Winneba. Journal of Science and Mathematics Education,15(1).

Available at: http:// www .files.eric. ed.gov/ full text/ ED538533.pdf

Wilson, K. R., Wallin, .J. S., \& Reiser, C. (2003). Social stratification and the digital divide. Social Science Computer Review, 21, pp.133-143.

Zin, N.A.M,. Judi, H.M, . Mukti, .N.A., Amin, H.M., Sahra, .S., Ahmad, K., Ayob, .M.,\& Abdullah, Z. (2000). Gender differences in computer literacy level among undergraduate students in at University Kebangsaan Malaysia. EJISDC, 1(3), pp.1-8. 